\title{
(一般講演 )
}

1.ケタラール麻酔後ネンブタール麻酔した時の事故経験

\author{
諸星 康雄（北里大・医）
}

ケタラールによる麻酔は、投与法が簡易なこと、副作用が少ないことおよび覚醒が早いことな ぞ、沢山の利点から使用者に喜ばれ、私も実験時には好んで使用しているが、心電図の記録に当 って特異な所見(ノッチ)が現れることがある。この異常所見については、実験動物研究会（郮

・5 2 ) に報告したが、ノッチの観察経過中に 2 例の呼吸停止を経験した。

その 1 ) 猫 12 ケ月令 $(3 \mathrm{~kg})$ 近交蕃殖のヶージ飼い 牡

ケタラール（25 mg/ kg ）筋注し1 5 分間無反応な時期を経過した後、次第に諸反射、反応が 現れてきたが、痛覚が現れたと判断した時ネンブタール（25 mg/kg）を静注したところ、呼吸 停止が現れ、心電図上には心房と心室の関係が断たれた所見や諸波の持続時間の延長がみられた。 この猫には人工呼吸器を装着し手当したが、30 分後に突然心停止した。

人工呼吸はハーバード社製の陽圧式人工呼吸器を使用し、毎回 150 ～2 00 mlの純酸素を供 給したが、供給量と吸気量の関係を調節するため、チューブにはバイパスを設け、過剩な酸素を 水中に逃がし、バイパスからの排気（泡）の出具合と胸部のふくらみによってバイパス先の水深 を調節した。

その 2 ) 猫 4 ケ月令 $(1.2 \mathrm{~kg})$ 近交蕃殖のケージ飼い 牡

ケタラール $(25 \mathrm{mg} / \mathrm{kg})$ 麻醉後ネンブタール $(25 \mathrm{mg} / \mathrm{kg})$ を静注し、3 分後に呼吸停止が 起った。この猫にはべメグリッド（１5 mg/kg）を静注し、人工呼吸器にて呼吸管理したところ、 20 分後には弱いながらも自発呼吸が現れ、3時間後には痛覚を訴えるほど覚醒した。

MEMO 


\section{(一般講演 )}

\section{2. 麻酔事故に関する 2,3 の考察}

○網本昭輝・多川政弘・黒川和雄（日獣大）

1.クロロホルム吸入実験中に発生した麻酔性ショックについて。

吸入麻酔における肝機能を検査する実験の途中、クロロホルム吸入麻酔群の 1 例に麻酔性ショ ックの発生を見た。実験犬は麻酔中、ポリグラフにより血圧と心電図を持続的に記録し、心電計 の針の動きだけで麻酔が順調に進行しているものと思っていた。ところがクロロホルム吸入から 15 分後に、動脈血が採血できないことに気づき、血圧を見ると、その時はすでに $10-20 \mathrm{~mm}$ $\mathrm{Hg}$ となっていた。純酸素で人工呼吸、心蔵、ッサージ、補液、アドレナリン、メイロンなどの 投与処置により 11 分後に蘇生に成功した。しかし覚醒後、起立・採食が不可能となったため一 週間後に安楽死を行なった。この麻酔性ショックは気化器の故障により高濃度のガスを吸入した ことが原因であったが、事故を未然に防ぎえなかったのは、何回も麻酔実験を行なって慣れを生 じ、一部の器械に頼り一番基礎的な臨床的事項の観察をおこなったためである。

2. 吸入麻酔時における調節呼吸の注意点について

犬に $2.5 \%$ ハロセンで 3 時間にわたる吸入麻酔実験を行なった。麻酔を自律呼吸と調節呼吸 で維持したものに分けてそれぞれ観察したところ、後者の方が血圧、体温の下降が大きく、また 覚醒・回復までの時間も長くかかった。調節呼吸を行うと胸腔内の圧が上昇し、血液の還流が悪 くなり血王は下降ぎみとなる。また換気量の増大により、麻酔深度が深くなり麻酔中の事故発生 につながることがある。したがって調節呼吸で麻酔を維持する時、特にレスピレータ一使用時な どは麻酔深度の調節には十分な注意を払わなければならない。

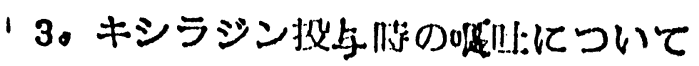

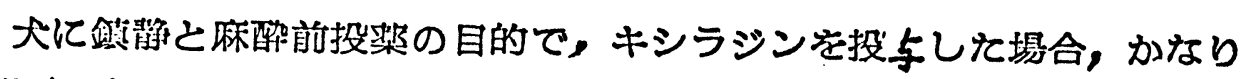
高い非度 (33.3-59.5\%)で因吐が発生するととが報告されている、今 回，演者らは，27頭の絶食大に対してキシラジンを投与する前に，硫酸 アトロピシ及び制站郕（プリンペラン）を投与したととろ, キシラジン 投与後の呕吐の発生頉度が18.5\%で低い值を示したのてその概要を報告 する. 


\section{(一般講演 )}

\section{3. 過剩麻酔の呼吸抑制に対する塩酸ドキサプラム の効果について}

○若尾義人・高橋＼cjkstart貢・信田卓男・杉田喜興春・ 黒松勇蔵・新迫高志・北 昂 ( 麻布大)

第 16 回麻酔研究会において塩酸ドキサプラムの循環器および呼吸器に対する影響について報 告し、比較的強い呼吸促進作用が認められたが、本薬剤の投与量、投与方法あるいは肺換気量に ついては十分な検討がなされていなかった。

そこで今回は塩酸ドキサプラムの投与量、投与方法ならびに肺換気量などについて検討した結 果、若干の知見が得られたのでその成績について報告する。

実験材料ならびに方法

Pentobarbital $25 \mathrm{mg} / k g$ を投与して通常の麻醉を行い 10 分を経過した時点で 15 $\mathrm{mg} / \mathrm{kg}$ または $20 \mathrm{mg} / \mathrm{kg}$ を追加して過剩麻酔を行ったのち、塩酸ドキサプラムを投与しない control 群、塩酸ドキサプラム $1 \mathrm{mg} / \mathrm{kg}$ および $3 \mathrm{mg} / \mathrm{kg}$ の One shot投与群および 1 $m g / k g$ の点滴投与群の 3 群に分けて実験を行い、40 分間における分時換気量、呼吸数、血液力 スおよび血圧の変化について経時的な観察を行った。

\section{実験成績}

過㮃麻醉後、塩酸ドキサプラム $1 \mathrm{mg} / \mathrm{kg}$ および $3 \mathrm{mg} / \mathrm{kg}$ の One shot 投与群において は、分時換気量、呼吸数、 $\mathrm{Po}_{2}$ および血圧は両者ともに塩酸ドキサプラム投与直後において著 明に增加し、以後は除々に回復する傾向がみられた。このような反応は投与量の増加にともなっ て增強する傾向が認められたが、1 $\mathrm{mg} / \mathrm{kg}$ の投与量では、Control 群に比較してほとんど反応 に差異が認められない例もあったことから、One shot 投与群では $3 \mathrm{mg} / \mathrm{kg}$ の投与量が有効 であろうと推察された。また、Pentbarbital $20 \mathrm{mg} / \mathrm{kg}$ で過㮃麻酔後、塩酸ドキサプラム $1 \mathrm{mg} / \mathrm{kg}$ の点滴投与群では、血圧にも著明な変化はみられず、死の転帰をとった例もみられなか ったことから、比較的Risk の高いイヌにおける麻酔の呼吸抑制を予防する目的には、この方法 がかなり有効であろうと思われた。

しかしながら、今回の実験成績は健康犬における成績であり、今後、実際の臨床例に対する投 与量あるいは投与方法などについて、さらに検討を加える必要があると考えている。

MEMO 


\section{（一般講演）}

\section{2 ・ 3 の麻酔事故例について}

○竹内 啓・小川博之・佐々木伸雄（東大）

近年における麻醉管理技術の進歩により麻醉事故は著しく減少したが、それでもなお手術に伴 う事故例の中には、麻酔管理に原因があると考えられる例が少なくない。以下 $2 、 3$ の例につい て反省・対策を中心に述べる。

[イ ヌの G O F 麻酔前に発見し得なかった脳腫瘍に起因すると思われる脳死の 1 例]：本例は 一般所見および血夜所見に異常の認められなかった 7 才の雄の秋田犬で、G O F 麻酔下で陰葝の 可移植性性器肉腫の摘出手術を行ったが、心機能に異常が認められないにもかかわらず自発呼吸 ・諸反射が術後数時間を経ても出現せず、脳波がフラットなところからいわゆる脳死と判定した 症例で、約 50 時間後に心停止がみられた。本例では、剖検により左側梨状葉の細網細胞肉腫な らびに脳全体の水腫样変化が認められたので、事故時の所見を考慮すると、潜在していた脳の占 拠性病変による頭蓋内圧の上昇が G O F 麻酔により増悪された結果、脳へルニア（多分小脳扁桃 ヘルニア）の生じた可能性が強いと思われる。

〔ブタの吸入麻酔時にみられた悪性過高熱様症状について〕：ハロセンおよびェーテルを用い てブタの開腹手術を行った中の数例において、ヒトの悪性過高熱とよく似た事故に遭遇した。い ずれも、麻醉開始後 $20-30$ 分経過して手術麻酔期に維持されていたにもかかわらず、体温の 異常上昇、心拍数、呼吸数の增加、筋緊張の出現などがみられ、短時間のうちに心停止をきたし たものである。剖検時には、筋肉に著明な煮肉様変化が認められた。

〔術後無尿の発見遅延のため術後腎不全の改善ができなかった重度の子宮蓄膿症の 1 例〕: 通 常プアリスクの動物を全身麻酔下で手術する場合には、術前から術後にかけて尿カテーテルを留 置し、術後腎不全の早期発見につとめているが、手違いのためGOF麻醉後 24 時間以上を経て 無尿に気付いた 1 例では、その後連日連夜の補液、利尿、腹膜灌流などの処置にもかかわらず尿 生成がみられず、5 日後に死亡した。

〔ハロセンの反復使用後にみられたイ又の肝障害例について〕：ヒトでは八ロセンを短期間内 に反復使用した場合には肝壊死が高率に発生するといわれているが、動物での報告は少ない。G OF麻酔を用いてイ又の左側および右側の乳腺腫瘍摘出手術を 2 週間間隔で寒施したところ、第 2 回手術の約 1 週間後から全身状態の悪化ならびに血清 G P T および A L P の増加などがみられ た。キシリトール、ビタミン剤などの点滴注射により、約 1 ケ月後に全身状態は完全に回復した が、G P Tおよび A L P の減少には、より長期間を要した。

\section{MEMO}




\section{(一般講演)}

\section{5. ウマの halothane-oxygen 麻酔に おける事故例について}

\section{$\bigcirc$ 吉田慎三・竹永士郎・原 秀昭（日競研）}

競走馬総合研究所においては、昭和 39 年以来現在（昭和 52 年 8 月末日）に至るまでウマの halothane-oxygen 麻酔を実施してきたが、この麻酔法の前投薬、倒馬薬については若干の 変遷を経てきている。

この間、記録上では 664 頭の麻酔を実施したが、その内訳は、競走馬および乗馬の麻酔手術 例 225 例、実験的手術に供用した例、409例であった。この他、麻醉実験、研修等に約 200 例を供用した。

これら 664 例の年令は、明 2 才から 21 才まで平均 4.8 才であり、体重は $230 \mathrm{~kg}$ から 614 $k g$ まで平均 $481 \mathrm{~kg}$ の範囲内にあった。

664 例の麻醉中における麻酔事故は 25 例であり、その内容は口唇麻瘏 4 例、橈骨神経麻痺 12 例、術後の呼吸困難 3 例、疝痛 3 例、外傷その他 3 例であった。

これらの麻酔事故の発生経過についてみると、口唇麻痺は hal othane--oxygen 麻䣲開始 の初期に発生しており、橈骨神経麻瘴は体重の重い例（５００ｋｇ以上）でかつまた麻醉時間の長 時間にわたった症例に発生する傾向があった。これらの麻瘒は、翌日には消失している例から、 完全な治瘾までに 6 力月を要した例もあった。

術後の呼吸困難は、喘鳴症手術後に発生した例、および気管チューブの拥入不手際の症例にお いて認められた。

外傷は起立時の騒擾による例であり、その他は、重い前投薬による再入眠の例であった。

死亡例は 3 例であったが、1 例は術後 12 時間を経過して死に至り、1 例は倒馬の際の大動脈 破裂によって死亡し、残る 1 例は halothane の過剩吸入が原因であった。

以上の事故例は、いずれも良好な健康状態下で発生した麻酔事故例であり、われわれの経験で はいわゆる poor risk 下での事故発生はきわめて少なかった。

MEM O 


\section{特 別 講 演}

\section{麻酔事故とその対策}

神戸大学医学部助教授 (麻醉学教室) 医学博士 森川 定雄

全身麻酔により起こる合併症には表 1 のごとく多くのものがある。この内の主なものには以下 のごとくである。

表 1. 全身麻酔の合併症

\begin{tabular}{|c|c|c|c|c|}
\hline 循環系合併症 & 呼吸系合併症 & 消化系合併症 & 神経系合併症 & そ の \\
\hline 1.低血圧、ショック & 1.気道閉塞 & 1. 胃拡張 & 1.覚醒の遅延、遷 & 1.発熱、発汗、悪 \\
\hline 2.不整脈 & 2.呼吸抑制、無呼 & 2.しやっくり & 延性無呼吸 & 性高体温 \\
\hline 3.心停止 & 吸 & 3.悪心、嘔吐、 & 2.サクラン & 2.体温の下降、ふ \\
\hline 4.高血圧 & 3.過呼吸(頻呼吸) & 誤飲、䇪兒、 & 3.ケイレン & るえ \\
\hline \multirow[t]{7}{*}{ 5.心不全、肺水腫 } & 4. 喉頭ヶイレン、 & 肺炎 & 4.末梢神経 マヒ & 3.皮フ炎、組織壊 \\
\hline & 気管支ケイレ & & 5.眼の損傷 & 死、動脈炎 \\
\hline & ン & & 6.声帯損傷、嘎声、 & 4.歯の損傷、耳下 \\
\hline & 5.気胸、無気肺 & & 声門浮腫 & $\begin{array}{l}\text { 腺炎、口内炎 } \\
\text { 5.排尿困難 }\end{array}$ \\
\hline & & & & 6.爆発、燃焼 \\
\hline & & & & $\begin{array}{l}\text { 7.輸血、輸夜の合 } \\
\text { 併症 }\end{array}$ \\
\hline & & & & $\begin{array}{l}\text { 8.麻酔器、バイビ } \\
\text { ソグ事故 }\end{array}$ \\
\hline
\end{tabular}

MEMO 


\section{I 循環系合併症}

1. 低血圧、ショック

原因には、麻酔剤によるもの、出血、患者に原因のあるものなどが考えられる。処置は、麻酔 剤の投与の中止、 $\mathrm{O}_{2}$ 投与と人工呼吸、輸夜、昇圧剤・強心剤の投与が主なものである。長時間 の手術、出血が考えられる手術では静脈を確保する必要がある。手術中の輸夜に用いられるもの

表 2. 輸液に用いられるもの

\begin{tabular}{|c|c|c|c|}
\hline 糖 & 電 解 質 液 & 代用 血 漿㓣 & 血 液、血 液製 剂 \\
\hline $\begin{array}{l}\text { 1.ブドウ糖 } \\
\text { 2.果糖 } \\
\text { 3.ソルビトール } \\
\text { 4.キシリトー・ } \\
\text { 5.マルトース }\end{array}$ & $\begin{array}{l}\text { 1.生理的食塩水 } \\
\text { 2.リンゲル液 } \\
\text { 3.乳酸化リンゲル液 } \\
\text { 4.糖加電解質液 } \\
\text { 5.その他（電解質 + } \\
\quad \text { ，酸、デキストラ } \\
\text { ン） }\end{array}$ & $\begin{array}{l}\text { 1.デキストラン } 70 \\
\text { 2.デキストラン } 40 \\
\text { ( 低分子) } \\
\text { 3.Modified Fluid } \\
\text { Gelatin } \\
\text { 4.Hydroxy Ethyl } \\
\text { Starch (HES) }\end{array}$ & 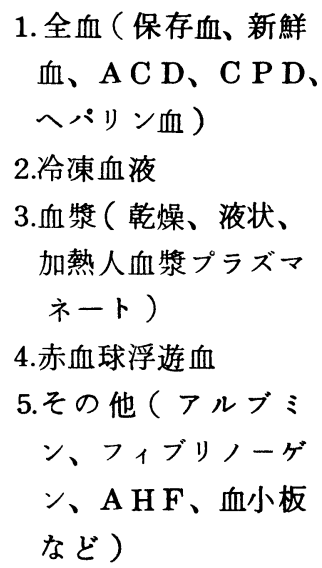 \\
\hline
\end{tabular}

は表 2 のごとく多くのものがあるが、最近では細胞外液、血漿の電解質と同一組成の液がよく用 いられる。出血には血液に代ってこの乳酸化りンゲル夜と代用血漿（デキストラン、ゲラチン、

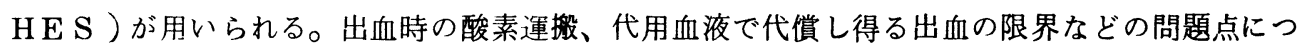
き述べる。

舁圧剤、強心薬には表 3 のようなものが用いられる。有効かどうかの目やすは、脈拍の改善、 皮膚色の改善、末梢血液の改善などであり、状態を見ながら少量ずつ追加する方が安全である。 MEM O 
表 3. 昇圧薬、血管収縮薬

\begin{tabular}{|c|c|c|}
\hline & 単 & 投 与 \\
\hline $\begin{array}{l}\text { I soproterenol } \\
(\text { プロタノール・L }) \\
(\text { スーナー・L })\end{array}$ & $\begin{array}{l}0.2 \mathrm{mg}, 1 \mathrm{~m} \ell \\
1 \mathrm{mg}, 1 \mathrm{~m} \ell\end{array}$ & $0.2 \sim 1.0 \mathrm{mg} / 500 \mathrm{~m} \ell \quad$ I.V.Drip \\
\hline $\begin{array}{l}\text { Carnigen } \\
\quad(\text { カルニゲン })\end{array}$ & $2 m_{\ell}$ & $\begin{array}{l}0.5 \sim 1.0 \mathrm{~m} \ell \text { I.V. } \\
2 \sim 10 \mathrm{~m} \ell / 200 \mathrm{~m} \ell \quad \mathrm{I} . \mathrm{V} . \mathrm{D} . \\
1 \sim 2 \mathrm{~m} \ell \text { I.M. or S.C. }\end{array}$ \\
\hline $\begin{array}{l}\text { Ethyl phenyl ephrine } \\
(\text { エホチール) }\end{array}$ & $10 \mathrm{mg}, 1 \mathrm{~m} \ell$ & $\begin{array}{l}3 \sim 5 \mathrm{mg} \text { I.V. } \\
10 \sim 30 \mathrm{mg} / 500 \mathrm{m \ell} \quad \mathrm{I} . \mathrm{V} . \mathrm{D} . \\
10 \mathrm{mg} \text { I.M. or S.C. }\end{array}$ \\
\hline $\begin{array}{l}\text { Adrenal ine } \\
\text { Epinephrine } \\
\quad(\text { ボスミン) }\end{array}$ & $1 \mathrm{mg}, 1 \mathrm{m \ell}$ & $\begin{array}{l}0.5 \sim 1 \mathrm{mg} / 5 \sim 10 \mathrm{~m} \ell \text { 心室内人 } \\
0.2 \sim 0.4 \mathrm{mg} \quad \text { I.V. } 1 \mathrm{mg} / 500 \mathrm{~m} \ell \quad \text { I.V.D. } \\
0.25 \sim 0.5 \mathrm{mg} \quad \text { I.M. }\end{array}$ \\
\hline $\begin{array}{l}\text { Noradrenal ine } \\
\text { Norepinephrine }\end{array}$ & $1 \mathrm{mg}, 1 \mathrm{~m} \ell$ & $\begin{array}{l}1 \sim 5 \mathrm{mg} / 500 \mathrm{ml} \quad \mathrm{I} . \mathrm{V} . \mathrm{D} . \\
0.25 \mathrm{mg} \text { I } . \mathrm{V} . \mathrm{mg} / 500 \mathrm{ml} \quad \mathrm{I} . \mathrm{V} \cdot \mathrm{D} . \\
0.5 \sim 1 \mathrm{mg} \quad \mathrm{I} . \mathrm{M} .\end{array}$ \\
\hline $\begin{array}{l}\text { Ephedrine' } \\
\quad \text { (塩酸エフェドリン) }\end{array}$ & $40 \mathrm{mg}, 1 \mathrm{m \ell}$ & $\begin{array}{l}20 \sim 40 \mathrm{mg} \text { I.V. } \\
40 \mathrm{mg} \quad \mathrm{I} . \mathrm{M} . \text { or S.C. }\end{array}$ \\
\hline $\begin{array}{l}\text { Metaraminol } \\
\quad(\text { アラミノン ) }\end{array}$ & $10 \mathrm{mg}, 1 \mathrm{~m} \ell$ & $\begin{array}{l}0.5 \sim 1 \mathrm{mg} \quad \mathrm{I} . \mathrm{V} . ., \quad 2 \sim 5 \mathrm{mg} \\
10 \sim 20 \mathrm{mg} / 50 \\
10 \mathrm{~m} \ell\end{array}$ \\
\hline 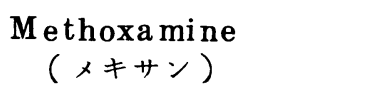 & $10 \mathrm{mg}, 1 \mathrm{~m} \ell$ & $\begin{array}{llll}1 \sim 5 \mathrm{mg} & \text { I.V., } & 5 \sim 10 \mathrm{mg} & \text { I.M. } \\
10 \sim 2 & 0 \mathrm{mg} / 500 \mathrm{~m} \ell & \text { I.V.D }\end{array}$ \\
\hline $\begin{array}{l}\text { Phenylephrine } \\
\quad(\text { ネオシネジン) }\end{array}$ & $\begin{array}{l}1 \text { 号, } 1 \mathrm{mg}, 1 \mathrm{m \ell} \\
2 \text { 号, } 5 \mathrm{mg}, 1 \mathrm{m \ell}\end{array}$ & $\begin{array}{llll}0.2 \sim 0.5 \mathrm{mg} & \text { I.V. } & 1 \sim 5 \mathrm{mg} & \text { I } . \mathrm{M} \\
2 \sim 5 \mathrm{mg} / 5 & 00 \mathrm{~m} \ell & \text { I.V.D. } & \end{array}$ \\
\hline Dopamine & $10 \mathrm{mg}, 1 \mathrm{~m} \ell$ & $10 \mathrm{mg} / 100 \mathrm{m \ell} \quad$ I.V. Drip \\
\hline
\end{tabular}

（岩月賢一監修：I C Uハンドブック 克誠堂出版, 東京，P546１976より引用） MEMO 
などであり、状態を見ながら少量ずつ追加する方が安全である。

\section{2. 不整脈}

麻酔中の不整脈は非常に多い。原因も多様であり、頻脈、除脈、心室性期外収縮などがよく見 られる。ヒトで心電図を持続的に測定した例では、30〜60\%の高頻度に不整脈が発生したと の報告がある。麻酔中の不整脈は、年令、性、麻醉法、麻酔剤などによる差は少なく、麻醉前の 心臓血管系疾患、不整脈の存在が最も大きい因子と言われ特に挿管時に多い。しかし急死にいた る危険な不整脈（頻発する心室性期外収縮、房室ブロック、心室細動など）は非常に少なく、全 不整脈の $1 \%$ 以下であ。不整脈の治療法、治療薬の主なものを表 4 に示す。

表 4. 主な抗不整脈薬

\begin{tabular}{|c|c|c|}
\hline & 単位 & 投 与 法 \\
\hline $\begin{array}{l}\text { Lidocaine } \\
\quad(\text { キシロカイン })\end{array}$ & $\begin{array}{l}1 \% \cdot 2 \% \\
20 \mathrm{m \ell}\end{array}$ & $\begin{array}{l}\text { 通常 } 1 \mathrm{mg} / 1 \mathrm{~kg} \text { I.V. } \\
\text { または } 1 \sim 2 \mathrm{mg} / \text { 分で点滴 }\end{array}$ \\
\hline $\begin{array}{l}\text { Procaine amide } \\
(\text { (アミサリン) }\end{array}$ & 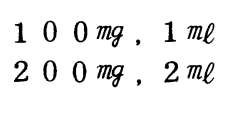 & 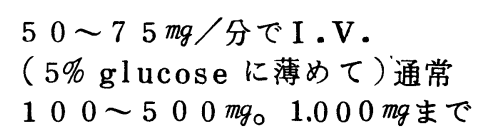 \\
\hline $\begin{array}{l}\text { D iphenylhydantoin } \\
\text { ( アレビフチン) }\end{array}$ & $\begin{array}{l}250 \mathrm{mg}, 1 \text { 瓶 } \\
(\text { 溶解液 } 5 \mathrm{~m} \ell \text { ) }\end{array}$ & 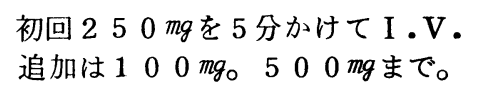 \\
\hline $\begin{array}{l}\text { Propranolol } \\
(\text { インデラル) }\end{array}$ & $2 \mathrm{mg}, 2 \mathrm{m \ell}$ & $\begin{array}{l}2 m g \text { を } 5 \text { 分かけて } 1 . V . \text { 追加は } \\
2 \sim 3 \text { 分観察後 } 2 m g 。\end{array}$ \\
\hline Quinidine sulfate & $100 \mathrm{mg}, 1$ 錠 & $\begin{array}{l}\text { 経口投与。まず } 100 \mathrm{mg} \text { で過敏反応 } \\
\text { テスト。 } 1 \text { 日 } 0.6 \sim 1.2 \mathrm{~g} \text { を } 3 \sim 4 \\
\text { 回に分服。 }\end{array}$ \\
\hline
\end{tabular}

（岩月賢一監修：I C Uハンドブック 克誠堂出版, 東京，P545，1976より引用）

\section{MEM O}




\section{3. 心停止}

麻醉合併症中最も恐ろしいもので非常に稀にしか起こらないが起った時には敏速で適切な処置 が必要である。心停止時の処置については、アメリカ心蔵協会、日本救急医学会などでその指針 がほぼ確定しているのでそれに従う。すなわち
(1) 気道の確保
(2) 人工呼吸
(3)心臓マッサージ（開胸、非開胸）
(4) 救急蘇生薬 ( 表 5 )
(5)除細動

などがその主なものである。

\section{MEMO}


表 5, 救急蘇生薬 (日本救急医学会推奨)

\begin{tabular}{|c|c|c|c|}
\hline 一 般 名 & 商 品 名 & 用 & 注 \\
\hline 重炭酸ナトリウム & $\begin{array}{l}\text { メイロン }(7 \%, \\
50 \mathrm{m \ell})\end{array}$ & $1 \sim 1.2 \mathrm{~m} \ell / \mathrm{kg}$ & $\begin{array}{l}\mathrm{pH} \text { 測定と塩基欠乏を計算 } \\
\text { の後増量してもよい。 }\end{array}$ \\
\hline エピネフリン & $\begin{array}{l}\text { 塩化アドリナリン注射液 } \\
\text { ボスミン注射液 } \\
(0.1 \%, 1 \mathrm{m \ell})\end{array}$ & 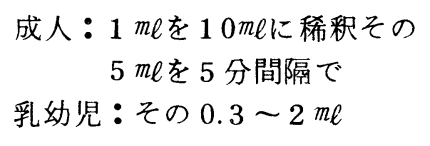 & 心腔内、気管内投与も可 \\
\hline 硫酸アトロピン & $\begin{array}{l}\text { 硫酸アトロピン } \\
(0.05 \%, 1 \mathrm{m \ell})\end{array}$ & $0.2 \mathrm{m \ell} / 10 \mathrm{~kg}$ & $\begin{array}{l}\text { 少量で徐脈 } \\
\text { 大量で尿貯留, 精神症状 }\end{array}$ \\
\hline 塩酸リドカイン & $\begin{array}{l}\text { 静注用キシロカイン } \\
(2 \%, 5 m \ell)\end{array}$ & 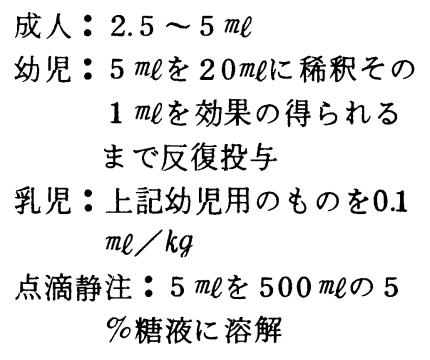 & $\begin{array}{l}\text { 必要効果のでるまで増量 } \\
100 \mathrm{mg} \text { 時をこえないよう }\end{array}$ \\
\hline 塩化カルシウム & $\begin{array}{l}\text { 塩カル注 } \\
(2 \%, 20 m \ell)\end{array}$ & $\begin{array}{l}5 \sim 10 \mathrm{m \ell} \\
\text { 最大 } \quad 1 \mathrm{m \ell} / \mathrm{kg}\end{array}$ & $\begin{array}{l}\text { ジギタリス剤を投与され } \\
\text { ているときは注意 }\end{array}$ \\
\hline
\end{tabular}

II 呼吸系合併症

1. 嘔吐、誤飲、窒息、肺炎

胃内容の嘔吐、気管内への誤飲、窒息、肺炎はヒトでは緊急手術や腸閉塞などの全麻時に時折 見られ、死亡率の高い恐ろしい合併症となる。予防が最も大切で、麻醉前の絶食水の厳守、輪状 軟骨圧迫による気管内插管などを行う。起こると間もなく表 6 のごとき症状が見られる。処置は 
表 6. 詔飲時の主要症状、検查所見

\begin{tabular}{|c|c|c|c|c|c|c|c|c|c|c|c|c|}
\hline 症 & $\begin{array}{l}\text { チ } \\
\text { J } \\
1 \\
\text { ゼ }\end{array}$ & $\begin{array}{c}\text { 最低 } \mathrm{PaO}_{2} \\
\mathrm{~mm} \mathrm{Hg} \\
\text { (吸入 } \mathrm{O}_{2} \\
\text { 濃度) }\end{array}$ & $\begin{array}{l}\text { シ } \\
\exists \\
\text { y } \\
\eta\end{array}$ & $\begin{array}{l}\text { 最低血圧 } \\
\mathrm{mmH} \mathrm{g}\end{array}$ & $\begin{array}{l}\text { 頻 脈 } \\
\text { 脈 拍 } \\
\text { 最 数 } \\
\text { 高 分 }\end{array}$ & $\begin{array}{l}\text { 呼多 } \\
\text { 复品 } \\
\text { 迫数 } \\
\text { 最分 }\end{array}$ & $\begin{array}{l}\text { 肺 } \\
\text { 水 } \\
\text { 腫 }\end{array}$ & $\begin{array}{c}\text { 最 高 } \\
\mathrm{CVP} \\
\mathrm{cmH}_{2} \mathrm{O}\end{array}$ & $\begin{array}{l}\text { 血 } \\
\text { 液 } \\
\text { 濃 } \\
\text { 縮 }\end{array}$ & $\begin{array}{c}\text { 最高 } \mathrm{H} t \text { 值 } \\
\% \\
\text { (日 時) }\end{array}$ & $\begin{array}{r}\text { 最低血清 } \\
\mathrm{Na} \text { 值 } \\
\mathrm{mEq} / \mathrm{L}\end{array}$ & $\begin{array}{l}\text { 最 } \\
\text { 倠 } \\
\dot{\mathrm{E}} \\
\dot{\mathrm{E}}\end{array}$ \\
\hline 1 & + & $\begin{array}{l}25(100 \% \\
\text { マスク) }\end{array}$ & + & $60 / 30$ & $\begin{array}{l}+ \\
(156)\end{array}$ & $\begin{array}{c}+ \\
(56)\end{array}$ & \pm & 15 & + & $\begin{array}{l}62.5 \\
(4 \text { 日目 })\end{array}$ & 136 & -8 \\
\hline 2 & + & $\begin{array}{c}40 \\
\text { ( 空気 ) }\end{array}$ & + & $60 / ?$ & $\begin{array}{c}+ \\
(120)\end{array}$ & $\begin{array}{c}+ \\
(36)\end{array}$ & + & & + & $\begin{array}{l}62 \\
(3 \text { 日目) }\end{array}$ & 138 & -12 \\
\hline 3 & + & $\begin{array}{l}55(100 \% \\
\text { バード) }\end{array}$ & + & $80 / ?$ & $\begin{array}{c}+ \\
(128)\end{array}$ & $\begin{array}{c}+ \\
(46)\end{array}$ & + & 12 & + & $\begin{array}{l}56 \\
(7 \text { 日目 })\end{array}$ & 111 & -5 \\
\hline 4 & + & $\begin{array}{l}45(100 \% \\
\text { バ-ド) }\end{array}$ & \pm & $80 / 60$ & $\begin{array}{c}+ \\
(132)\end{array}$ & $\begin{array}{c}+ \\
(48)\end{array}$ & - & & + & $\begin{array}{l}67 \\
(1 \text { 日目 })\end{array}$ & 116 & -17 \\
\hline 5 & - & $\begin{array}{l}75\left(\mathrm{O}_{2} \text { テ }\right. \\
\text { ント })\end{array}$ & - & $120 / 80$ & $\begin{array}{c}+ \\
(144)\end{array}$ & $\begin{array}{c}- \\
(22)\end{array}$ & - & & + & $\begin{array}{l}50 \\
(1 \text { 日目) }\end{array}$ & 133 & +2.9 \\
\hline 6 & - & $\begin{array}{l}143\left(\mathrm{O}_{2}\right. \\
\text { テント })\end{array}$ & - & $100 / 80$ & - & - & - & & - & $\begin{array}{l}39 \\
(1 \text { 日目 })\end{array}$ & & \pm 0 \\
\hline
\end{tabular}

（森川定雄ほか：Aspiration Pneumonia 麻酔 22:465,1973より引用）

気管内插管、吸引、気管内洗浄、副腎皮質ホルモン、抗生物質などの投与である。ヒトの場合死 亡率は高く、しばしばレスピターによる加圧人工呼吸の対象となる。

\section{2. 気道閉塞}

麻酔により意識が喪失すると特に舌根の沈下、分泌物により気道閉塞を起こし易い。また気管 内挿管により気道を確保しても、チューブに原因する種々の気道閉塞( 表 7 ) が起こるので安心 出来ない。

MEMO 
表 7. 気管内チューブのトラブル

( Ng TN, Kirimli Bl, Anesth, \& Anglg. 54:710,1975)

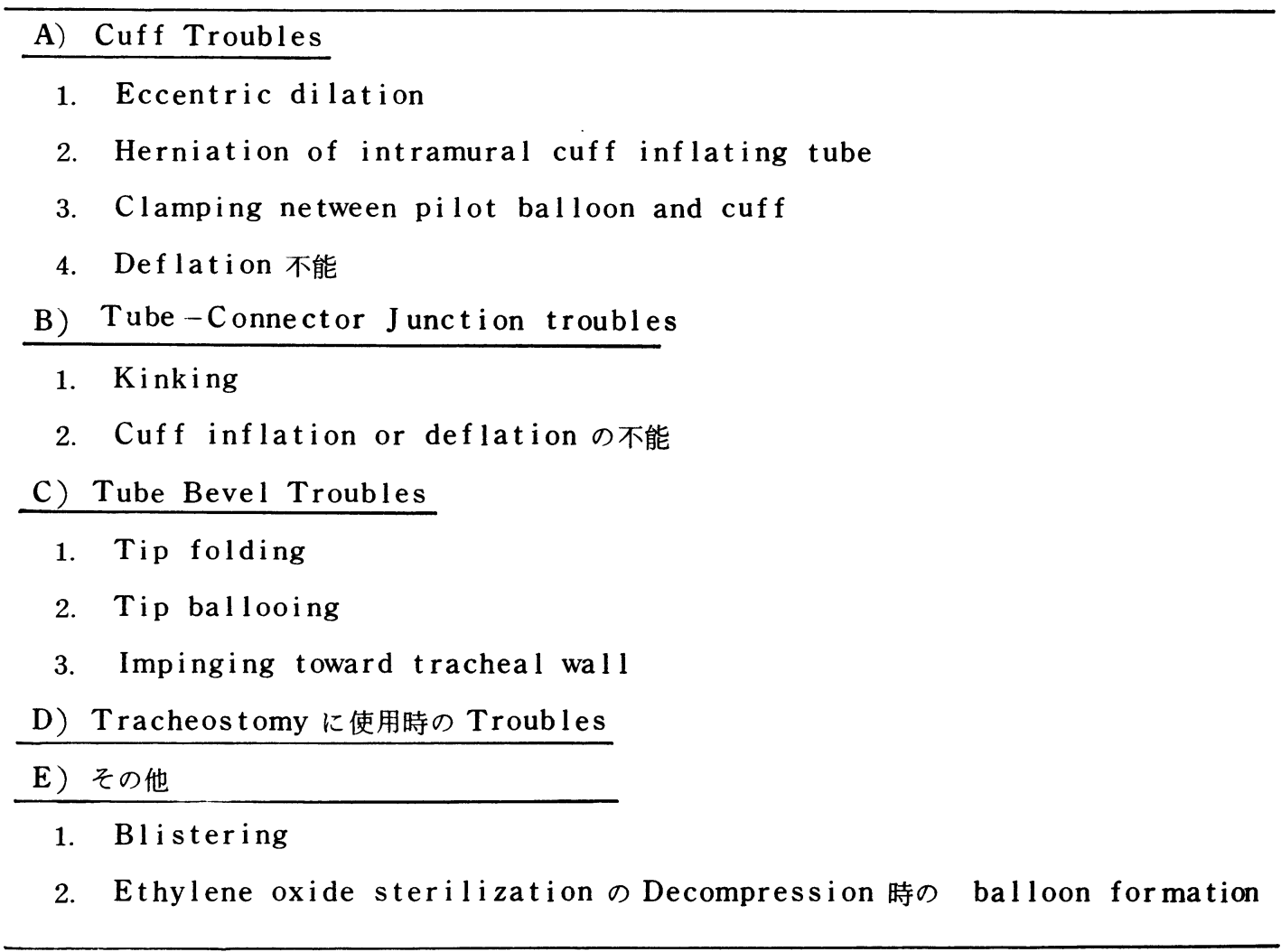

\section{3. 呼吸抑制、呼吸停止、過呼吸}

呼吸抑制の原因は大部分麻䣲剤の過㮃投与による。人工呼吸、補助呼吸を行う。過呼吸（頻呼 吸）の原因には多種あるが、浅麻酔、手術刺激、気道の部分閉塞、 $\mathrm{CO}_{2}$ の蓄積などによること が多い。気道をチェックし、麻酔を深くし、時折補助呼吸をしてやるなどの処置をする。

MEMO 
III その 他

1. 麻醉器による機械的事故

近年笑気と酸素の間違いによる死亡例、事故が新聞にも報道され記億に新しい。この様な麻酔 器による事故は日常非常に多く見られるものである。表 8 は従来報告されたものや、わ机わ机自 身の経験をまとめたものである。

表 8 . 麻酔器による事故

A $\mathrm{O}_{2}$ でないガスの使用

1. 中央配管の事故

2. $\mathrm{O}_{2}$ ボンベの間違い $\left(\mathrm{C} \mathrm{O}_{2}, \mathrm{~N}_{2}, \mathrm{~N}_{2} \mathrm{O}\right)$

3. $\mathrm{O}_{2} \quad$ と $\mathrm{N}_{2} \mathrm{C}$ の接続の間違い

B 流 量 計

1. $\mathrm{O}_{2}$ 流量計の位置が不定 (U.S.A.右、ヨーロッパ左)

2. $\mathrm{O}_{2}$ の色が不定 (U.S.A.緑,ドイッ青, 日本黒)

3. 流量計のもれ

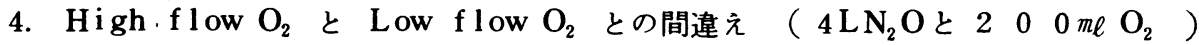

5. Inproperly Calibrated Flowmeter（特に Flowmeter tubeをとりかえた 時）

6. ダイアルの形、大きさがどの流量計でも同一

7. 流量計にごみがたまり流量が出ない。

C 気 化 器

1. Overfilling $\rightarrow$ Halothane bubbling

2. Vernitrol（Heidbrink） ～使用量が分りにくい時あり

3. Wrong agent in Vaporizer (Halothane in Pentec Vaporizer, $30 \%$ Ha lot hane)

MEMO 
4. Off が完全に Offにならない。

5. Inlet とOutlet の Miss $\rightarrow$ Overflow

6. Foaming (Cupper kettle, Penthrane)

7. $\mathrm{O}_{2}$ Flush 時に Halothane が出る。(Vernitrol)

8. Of $\mathrm{f}$ の方向を間違える。 $\rightarrow$ 高濃度

2. 体温の変化、悪性高体温

麻酔中には体温調節機能の喪失により多くは体温の低下を見るが長時間の手術では若干の上昇 を見るものもある。これらとは別に近年全麻中に体温が急上昇し、死亡率が高く治療も対症療法 にとどまるという症例が報告され悪性高体温 Malignant Hyperpyrexia or Hyperthermia と呼ばれ非常に問題となっている。動物でもブタ、犬などで同様の症候が発生する。この症候の 死亡率、症状、検查所見、治療法などは、今後の研究によって明かになろう。 